\title{
Hepatitis $B$ virus inhibits the in vivo and in vitro synthesis and secretion of apolipoprotein C3
}

\author{
Chengliang Zhu', Hengcheng Zhu' ${ }^{1}$, Hui Song ${ }^{2}$, Limin $\mathrm{Xu}^{2}$, Longxuan $\mathrm{Li}^{3}$, Fang Liu ${ }^{4}$ and Xinghui Liu²*
}

\begin{abstract}
Background: Hepatitis B virus (HBV) infection in the body can damage liver cells and cause disorders in blood lipid metabolism. Apolipoprotein C3 (ApoC3) plays an important role in the regulation of lipid metabolism, but no study on the HBV regulation of ApoC3 has been reported. This purpose of this study was to investigate the effect of HBV on ApoC3 expression and its regulatory mechanism.
\end{abstract}

Methods: The expression levels of ApoC3 mRNA and protein in the human hepatoma cell lines HepG2 and HepG2. 2.15 were determined using real-time quantitative reverse transcription polymerase chain reaction (RT-qPCR) and Western blot. The HepG2 cells were co-transfected with the ApoC3 gene promoter and either HBV-infected clone pHBV1.3 or its individual genes. The changes in luciferase activity were assayed. The expression levels of ApoC3 mRNA and protein were determined using RT-qPCR and Western blot. The content of ApoC3 in the supernatant of the cultured cells was determined using an enzyme-linked immunosorbent assay (ELISA). The sera were collected from 149 patients with HBV infection and 102 healthy subjects at physical examination as the normal controls. The serological levels of ApoC3 in the HBV group and the normal control group were determined using ELISA. The contents of serum triglyceride (TG) and very-low-density lipoprotein (VLDL) in the HBV patients and the normal control were determined using an automatic biochemical analyser.

Results: The expression levels of ApoC3 mRNA and protein were lower in the HepG2.2.15 cells than in the HepG2 cells. pHBV1.3 and its $X$ gene could inhibit the activity of the ApoC3 promoter and its mRNA and protein expression. The serum levels of ApoC3, VLDL and TG were $65.39 \pm 7.48 \mu \mathrm{g} / \mathrm{ml}, 1.24 \pm 0.49 \mathrm{mmol} / \mathrm{L}$, and $0.46 \pm 0$. $10 \mathrm{mmol} / \mathrm{L}$ in the HBV patients and $41.02 \pm 6.88 \mathrm{\mu g} / \mathrm{ml}, 0.76 \pm 0.21 \mathrm{mmol} / \mathrm{L}, 0.29 \pm 0.05 \mathrm{mmol} / \mathrm{L}$ in the normal controls, respectively, statistical analysis revealed significantly lower serum levels of ApoC3, VLDL and TG in HBV patients than in the normal controls $(P<0.05)$.

Conclusion: HBV can inhibit the in vivo and in vitro synthesis and secretion of ApoC3.

Keywords: Hepatitis B virus, Apolipoprotein C3, Triglyceride, Very-low-density lipoprotein

\section{Background}

Hepatitis B virus (HBV) is a hepatotropic DNA virus. After HBV infects the body, approximately $10 \%$ of the infection can progress to a chronic infection. Currently, approximately 250 million people in the world are suffering from chronic hepatitis B or are chronic HBV carriers, and chronic HBV infection is a major factor leading to liver

\footnotetext{
* Correspondence: syliuxh@163.com

${ }^{2}$ Department of Clinical Laboratory, Shanghai Gongli Hospital, the Second Military Medical University, Pudong New Area, Shanghai 200135, China

Full list of author information is available at the end of the article
}

fibrosis and liver cancer. Approximately 3 million people with chronic HBV infection die of chronic B hepatitis, cirrhosis or liver cancer every year $[1,2]$.

The apolipoprotein (Apo) family is large and mainly includes apolipoproteins $\mathrm{A}, \mathrm{B}, \mathrm{C}$, and $\mathrm{E}$, which each are a special type of protein. Lipid must be combined with Apo in the process of normal transport [3]. Of the $C$ family members, apolipoprotein $\mathrm{C} 3$ (ApoC3) is seen at the highest concentration; its gene is located on the long arm q23 region of chromosome 11 and includes 4 exons and 3 introns. ApoC3 forms a gene family with Apo A1 
and A4 and is mostly synthesized in the liver, with a small amount synthesized in the small intestine [4]. As a main component of triacylglycerol-rich lipoprotein (TRL) and high-density lipoprotein (HDL), ApoC3 plays an important role in the regulation of lipid metabolism and can regulate the decomposition and metabolism of TRL in hypertriglyceridemia [5-7].

It was reported that HBV down-regulated the expression of ApoA1, ApoA5, ApoB and up-regulated the expression of ApoM [8-11].The main purpose of this study is to investigate the effect of HBV on the regulation of ApoC3 expression and its mechanism by in vivo and in vitro experiments.

\section{Materials and methods Study subjects}

A total of 149 patients with clinical diagnosis of hepatitis $B$ infection in the outpatient and inpatient departments were recruited, including 105 males and 44 females, with a mean age of $44.7 \pm 12.5$ years. Meanwhile, 102 healthy subjects who received a physical examination were recruited as the control group, which included 70 males and 32 females, with a mean age of $43.1 \pm 11.5$ years. Hepatotropic virus infections hepatitis A virus (HAV), hepatitis C virus (HCV) and hepatitis D virus (HDV), as well as other diseases that can cause metabolic abnormalities, were excluded in all patients. All subjects signed the informed consent, and this study was approved by the Ethics Committee of the hospital.

\section{Cell culture and transfection}

HepG2 and HepG2.2.15 cells were cultured in RPMI-1640 medium containing $10 \%$ foetal bovine serum, $100 \mathrm{U} / \mathrm{mL}$ penicillin and $100 \mathrm{mg} / \mathrm{L}$ streptomycin in a $37{ }^{\circ} \mathrm{C}$ incubator at $5 \% \mathrm{CO}_{2}$. Before the transfection, HepG2 cells were inoculated into 24-well plates or 6-well plates. When the cell confluence reached approximately $80 \%$, plasmid DNA and Lipofectin2000 transfection reagent were diluted in serumfree and penicillin-streptomycin-free RPMI-1640 medium at room temperature for $20 \mathrm{~min}$. The prepared transfection solution was added to the HepG2 cell culture medium, and the cells were incubated in the $\mathrm{CO}_{2}$ incubator.

\section{Determination of luciferase activity}

After transfection, the HepG2 cells were cultured for $48 \mathrm{~h}$, the supernatant was discarded, and the cells were washed with phosphate-buffered saline (PBS) before they were lysed with cell lysate buffer. After the cells were completely lysed, $20 \mu \mathrm{L}$ of cell lysate and $100 \mu \mathrm{L}$ of luciferase substrate were mixed and measured with a Luminometer. Each experiment was repeated three times.

\section{RT-qPCR}

HepG2 and HepG2.2.15 cells were harvested, and $1 \mathrm{~mL}$ of TRIzol ${ }^{\circ}$ reagent was added to extract the total RNA. After being treated with DNase, $1 \mu \mathrm{g}$ of RNA was used to synthesize cDNA by reverse transcriptase M-MLV. The ApoC3 gene was quantitatively measured using a SYBR $^{\circ}$ Green $^{\text {tux }}$ qPCR mix kit. The primers for ApoC3 were as follows: (sense) - 5'GTT ACA TGA AGC ACG CCA CC3' and (antisense) - 5'CAC GGC TGA AGT TGG TCT GA3'. GAPDH was used as the internal reference [12].

\section{Western blotting}

HepG2 and HepG2.2.15 cells were ultrasonically disrupted, and the supernatant was obtained. After an equal volume of loading buffer was added, the sample was boiled for $5 \mathrm{~min}$ and subjected to $12 \%$ sodium dodecyl sulfate-polyacrylamide gel electrophoresis (SDS-PAGE). After electrophoresis, the separated proteins were transferred onto a nitrocellulose (NC) membrane. After blocking with skim milk, 1:2000 polyclonal antibody for ApoC3 and 1:5000 goat anti-rabbit secondary antibody were each added, followed by the appropriate amount of electrochemiluminescence (ECL) solution. The membrane was placed in a gel imaging system to visualize the protein.

\section{ELISA detection}

The levels of ApoC3 in the serum and cell supernatant were measured by an enzyme-linked immunosorbent assay (ELISA) according to the manual of the ApoC3 ELISA kit. Each experiment was repeated three times.

\section{Biochemical testing}

The serum triglyceride (TG) level was measured according to the enzymatic principle using an automated biochemical analyser, and the very-low-density lipoprotein (VLDL) level was calculated according to Friedwald's equation.

\section{Statistical analysis}

SPSS20.0 statistical software was used for data processing. All data are presented as $\mathrm{X} \pm \mathrm{S}$. The comparison between groups was performed using t-tests. Difference with $P<0.05$ were considered statistically significant.

\section{Results}

\section{Baseline characteristics}

The clinical baseline characteristics of the participants are listed in Table 1. The serum HDL-C, LDL-C, TC, ApoA1 and $A p o B$ were significantly lower in $\mathrm{HBV}$ patients comparing with healthy individuals $(p<0.05)$, while there was no significant difference in gender, age and BMI between the two groups $(P>0.05)$. 
Table 1 Baseline characteristics of the subjects enrolled in the present study

\begin{tabular}{llll}
\hline Clinical parameters & $\begin{array}{l}\text { Healthy individuals } \\
(n=102)\end{array}$ & $\begin{array}{l}\text { HBV patients } \\
(n=149)\end{array}$ & $P$ \\
\hline Age (years) & $43.1 \pm 11.5$ & $44.7 \pm 12.5$ & 0.437 \\
Gender (male/female) & $70 / 32$ & $105 / 44$ & 0.397 \\
BMI & $24.7 \pm 1.4$ & $25.3 \pm 1.6$ & 0.485 \\
ALT(IU/l) & $<30$ & $215.2 \pm 262.5$ & $<0.01$ \\
AST(IU/l) & $<30$ & $139.5 \pm 182.4$ & $<0.01$ \\
TC $(\mathrm{mmol} / \mathrm{L})$ & $4.28 \pm 0.58$ & $3.86 \pm 0.75$ & $<0.01$ \\
HDL-C(mmol/L) & $1.62 \pm 0.27$ & $1.38 \pm 0.32$ & $<0.01$ \\
LDL-C $(\mathrm{mmol} / \mathrm{L})$ & $2.63 \pm 0.56$ & $2.25 \pm 0.55$ & $<0.01$ \\
ApoA1 $(\mathrm{g} / \mathrm{mL})$ & $1.38 \pm 0.16$ & $0.93 \pm 0.27$ & $<0.01$ \\
ApoB $(\mathrm{g} / \mathrm{mL})$ & $0.88 \pm 0.24$ & $0.73 \pm 0.18$ & $<0.01$ \\
\hline
\end{tabular}

\section{HBV inhibits the expression levels of ApoC3 mRNA and} protein

Using RT-qPCR and Western blot, the expression levels of ApoC3 mRNA and protein in HepG2 and HepG2.2.15 cells were determined. The results showed that the ApoC3 expression in HepG2.2.15 cells was lower than that in HepG2 control cells (Fig. 1a and b). Furthermore, the contents of ApoC3 in the HepG2 and HepG2.2.15 cell supernatants were determined by ELISA. The results showed that the expression levels of ApoC3 in HepG2 and HepG2.2.15 cells were $46.15 \pm 9.58 \mu \mathrm{g} / \mathrm{ml}$ and $28.02 \pm 8.46 \mu \mathrm{g} / \mathrm{ml}$, respectively, with a statistically significant difference $(P<0.05$, Fig. 1c), indicating that HBV can inhibit the expression of ApoC3 in HepG2 cells.
HBV inhibits the gene promoter activity and mRNA/ protein expression of $\mathrm{ApoC} 3$

pHBV1.3, an HBV-infected clone, and the ApoC3 gene promoter pApoC3-Luc were co-transfected into HepG2 cells, with pBlue-ks as the control plasmid. After $48 \mathrm{~h}$, the activity of the luciferase reporter gene was determined. The results showed that the activity of luciferase was $189.42 \pm 27.3 \mu \mathrm{g} /$ protein after transfection with pHBV1.3 and $857.36 \pm 55.6 \mu \mathrm{g} /$ protein after transfection with pBlue-ks; the difference was statistically significant (Fig. $4, P<0.05$ ), indicating that pHBV1.3 was able to inhibit ApoC3 gene promoter activity, as shown in Fig. 2a.

Furthermore, pHBV1.3 and its control plasmid pBlueks were transfected into HepG2 cells. After 48 h, the expression levels of ApoC3 mRNA and protein were determined by RT-qPCR and Western blot. The results showed that the expression levels of ApoC3 mRNA and protein were reduced in the HepG2 cells transfected with pHBV1.3 compared with the transfection control (Fig. 2b and c). Using ELISA, the content of ApoC3 in the cell supernatant was determined. The content of ApoC3 in the supernatant of HepG2 cells transfected with pHBV1.3 was $36.84 \pm 11.26 \mu \mathrm{g} / \mathrm{ml}$, which was lower than $95.53 \pm 17.31 \mu \mathrm{g} / \mathrm{ml}$ in the supernatant of HepG2 cells transfected with pBlue-ks (Fig. 2d).

\section{HBV inhibits ApoC3 expression through its $X$ gene}

HepG2 cells were co-transfected with all of the individual plasmid eukaryotic expression vectors containing the $\mathrm{HBV}$ genome and the ApoC3 gene promoter pApoC3-Luc, respectively, pCMV-tag2B was set as the control [11]. The results showed that the HBX significantly down-regulated the promoter activity of ApoC3 gene (Fig. 3a).

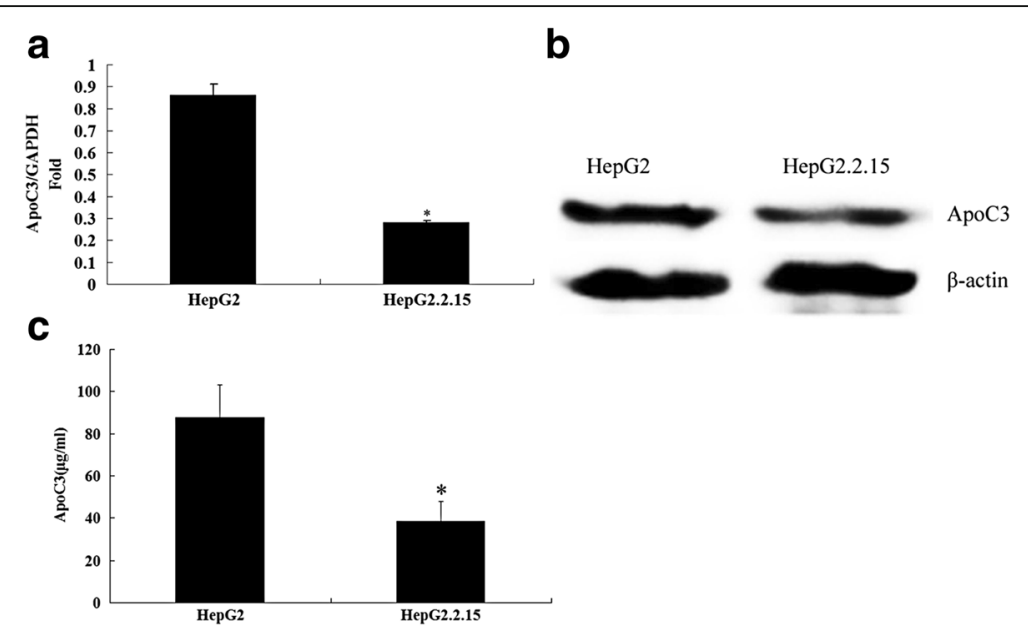

Fig. 1 Effect of HBV on ApoC3 mRNA and protein expression levels in HepG2 cells. a The total RNA of HepG2 and HepG2.2.15 cells was extracted, and the ApoC3 mRNA level was quantitatively determined by RT-qPCR; b The expression levels of ApoC3 protein in HepG2 and HepG2.2.15 were determined using Western blot; $\mathbf{c}$ The contents of ApoC3 in the supernatants of HepG2 and HepG2.2.15 cells were determined by ELISA. ${ }^{*} P<0.005$ 
a

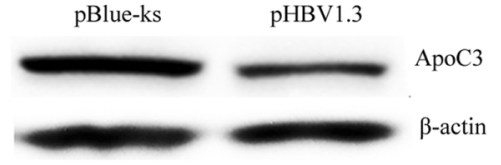

C

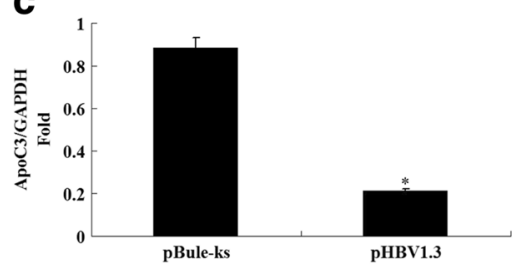

$\mathbf{b}_{5}$

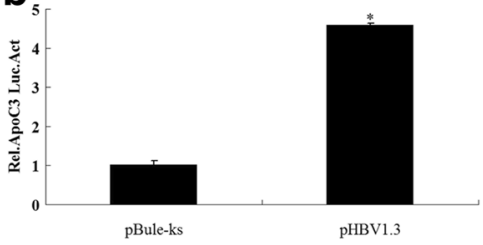

Fig. 2 Effect of pHBV1.3 on the promoter activity and mRNA and protein expression levels of ApoC3. a At $48 \mathrm{~h}$ after $0.6 \mu \mathrm{g}$ of pHBV1.3 and its control plasmid pBlue-ks were each co-transfected with $0.2 \mu \mathrm{g}$ of ApoC3 gene promoter pApoC3-Luc into HepG2 cells, the changes in luciferase activity were determined using a luminometer; each experiment was repeated three times; $\mathbf{b}$ at $48 \mathrm{~h}$ after $4 \mu \mathrm{g}$ of pHBV1.3 and its control plasmid pBlue-ks were each transfected into HepG2 cells, the effect of HBV on the expression of ApoC3 mRNA was determined by RT-qPCR; c The expression levels of ApoC3 protein in HepG2 and HepG2.2.15 cells were determined by Western blot; $\mathbf{d}$ The content of ApoC3 in the supernatant of HepG2 cells was determined by ELISA. *P < 0.005

Furthermore, HepG2.2.15 cells were transfected with HBX siRNA or its control (siRNA-NC) [13]. Results showed that ApoC3 mRNA and protein expression were significantly increased after transfection with $\mathrm{HBX}$ siRNA (Fig. 3b and c), and the content of ApoC3 in the supernatant of HepG2.2.15 cells transfected with HBX siRNA was $43.26 \pm 12.27 \mu \mathrm{g} / \mathrm{ml}$, which was higher than $27.65 \pm 7.88 \mu \mathrm{g} / \mathrm{ml}$ in the supernatant of HepG2.2.15 cells transfected with siRNA-NC (Fig. 3d), indicating that HBX inhibits the expression of ApoC3.

\section{Serum ApoC3 level of HBV patients was decreased}

The serum levels of ApoC3, TG and VLDL in the HBV patient group and the normal control group were tested.
The results showed that the serum levels of ApoC3, TG and VLDL were $65.39 \pm 7.48 \mu \mathrm{g} / \mathrm{ml}, 1.24 \pm 0.49 \mathrm{mmol} / \mathrm{L}$, and $0.46 \pm 0.10 \mathrm{mmol} / \mathrm{L}$ in the $\mathrm{HBV}$ group and $41.02 \pm$ $6.88 \mu \mathrm{g} / \mathrm{ml}, 0.76 \pm 0.21 \mathrm{mmol} / \mathrm{L}, 0.29 \pm 0.05 \mathrm{mmol} / \mathrm{L}$ in the normal control group, respectively, with statistically significant differences $(P<0.05)$, as shown in Fig. $4 \mathrm{a}-\mathrm{c}$.

\section{Discussion}

HepG2.2.15 cells are HepG2 cells that are stably transfected with the whole HBV genome, which can express all of the RNA and proteins of the virus and secrete virus-like particles [14]. Norton PA et al. screened for genes with differential expression in HepG2.2.15 and HepG2 cells by a DNA microarray and found that the
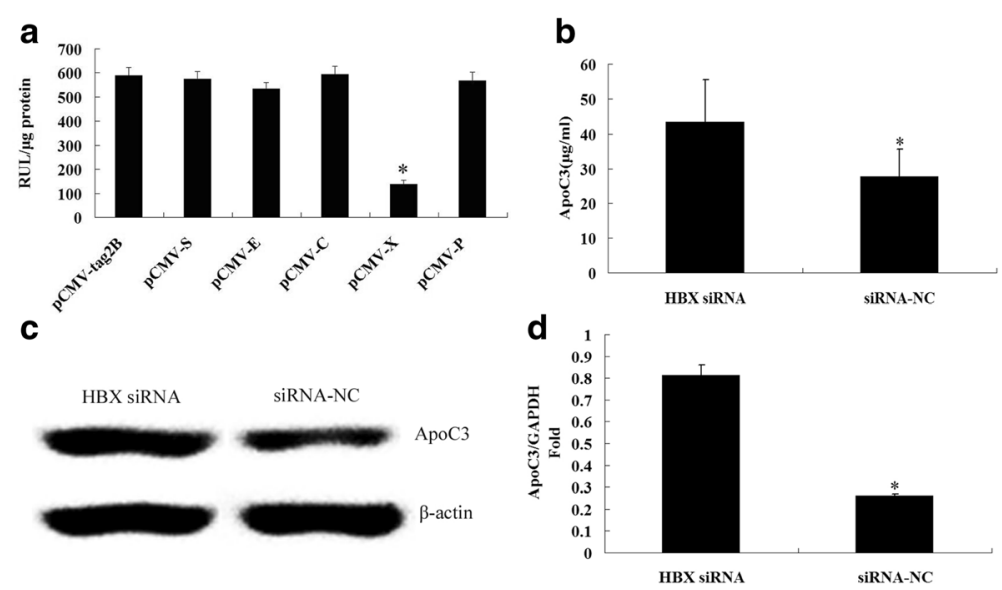

Fig. 3 HBV inhibited ApoC3 expression through its X gene. a HepG2 cells were transfected with pCMV-S, pCMV-E, pCMV-C, pCMV-X, pCMV-P and pCMV-tag2B, the changes in luciferase activity were determined using a luminometer at $48 \mathrm{~h}$ post-transfection, each experiment was repeated three times. $\mathbf{b}$ HepG2.2.15 cells were transfected with the HBX siRNA or the negative control siRNA(siRNA-NC) for 24 h. ApoC3 mRNA level was quantitatively determined by RT-qPCR; $\mathbf{c}$ The expression levels of ApoC3 protein in HepG2.2.15 cells were determined by Western blot; $\mathbf{d}$ The content of ApoC3 in the supernatant of HepG2.2.15 cells was determined by ELISA. ${ }^{*} \mathrm{P}<0.005$ 

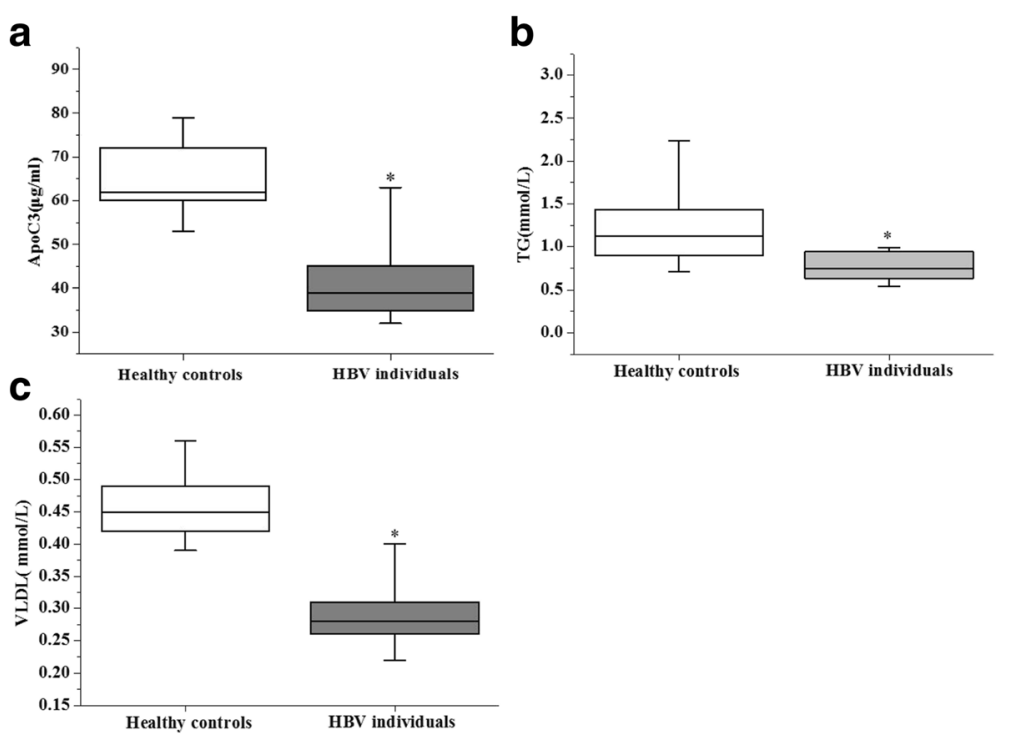

Fig. 4 Measurement of ApoC3, TG and VLDL in HBV patients and normal controls. a Comparison of the serum levels of ApoC3 in HBV patients and normal controls; $\mathbf{b}$ Comparison of the serum levels of TG in HBV patients and normal controls; c Comparison of the serum levels of VLDL in HBV patients and normal controls. ${ }^{*} \mathrm{P}<0.005$

expression levels of ApoA1, ApoB and ApoC3 in HepG2.2.15 cells were decreased [15]. Jiang $W$ and Wang $\mathrm{Y}$ confirmed the regulatory effect of $\mathrm{HBV}$ on ApoA1 [10, 16]. Our previous study also demonstrated the molecular mechanism of $\mathrm{HBV}$ inhibition of ApoB expression and found that HBV can inhibit the expression of ApoA5 [9, 11]. In this study, we found that the expression levels of ApoC3 mRNA and protein in HepG2.2.15 cells were lower than those in HepG2 cells, which is consistent with the microarray results of Norton PA. We also found that the expression levels of the ApoC3 promoter, mRNA and protein were inhibited by the transfection of the HBV-infected clone pHBV1.3 and HBV X gene. The examination of clinical specimens confirmed the regulatory effect of $\mathrm{HBV}$ on $\mathrm{ApoC} 3$ and showed that the serum ApoC3 level in HBV patients was decreased, indicating that $\mathrm{HBV}$ can inhibit the in vitro and in vivo synthesis and secretion of ApoC3.

The liver plays an important role in lipid metabolism, and it is not only the main site of lipid synthesis, transport, metabolism, and degradation but also an important site of lipoprotein degradation. A damaged or inflammatory state of liver cells can certainly influence lipid metabolism [17]. HBV infection will illicit the liver's inflammatory response by up-regulating the expression of inflammatory cytokines, such as interleukin (IL)-6, IL-12, IL-27 and IL-35, resulting in damage to liver cells, thus affecting the metabolism function of the liver and leading to abnormalities in lipoprotein synthesis [18-20].

Studies had shown that the blood lipid levels of HDL-C, LDL-C and TC in patients with $\mathrm{HBV}$ infection are significantly lower than those in healthy subjects [21, 22]. HBV can inhibit the expression of ApoA1 by inhibiting the activity of the ApoA1 promoter and inducing the hypermethylation of the ApoA1 promoter [16]. HBV can down-regulate the expression of $A p o B$ by inhibiting the expression of microsomal triglyceride transfer protein (MTP) [9]. HBV inhibits the expression of ApoA5 through its core gene [11]. In this study, we found that HBV could inhibit the expression of ApoC3 at the promoter, transcription and translation levels via its $\mathrm{X}$ gene. Accumulating evidence implied that HBX induces hypermethylation in the promoter region of many genes such as E-Cadherin, insulin-like growth factor-3, caveolin-1 and CD82 which results in their suppression [23-26], thus, HBV may inhibit the expression of ApoC3 through inducing hypermethylation of its promoter via HBX, and the detailed molecular mechanisms needs further investigation.

Subsequently, we compared the serum levels of TG and VLDL in HBV patients and normal controls and found that the serum levels of TG and VLDL were lower in $\mathrm{HBV}$ patients. ApoC3 is a lipoprotein lipase (LPL) inhibitor, which can inhibit the activities of lipase, hepatic lipase and lecithin cholesterol acyltransferase to affect lipid metabolism [27, 28]. LPL is a key enzyme in the catabolism of triglyceride lipoprotein (TRL) [29, 30]. When the ApoC3 expression decreases, the activity of LPL increases, the synthesis and secretion of VLDL decreases, and the decomposition of TG increases [31-33]. Therefore, the decreased serum levels of TG and VLDL in HBV patients may be related to the inhibition of ApoC3 expression by HBV. 


\section{Limitations}

However, there are two limitations of this study. Firstly, ApoC3 has many genetic polymorphic sites, which can affect the serological levels of TG and VLDL [7, 34]. For example, the T3206G polymorphism of the APOC3 gene is closely related to the blood lipids in hypertriglyceridemia, and the serum level of TG in ApoC3 G3175G genotype carriers is higher than those of other genotypes [35]. This study did not compare the differences in these ApoC3 polymorphisms in the HBV patients and normal controls. Secondly, other confounders related to lipid levels such as the habitual diet of the participants were not available, we could not include such variables in analysis. More rigorous design would be performed in the future study.

\section{Conclusion}

In conclusion, we investigated the regulatory effect of $\mathrm{HBV}$ on the expression of ApoC3 at the cell level and clinical level for the first time, laying the foundation for revealing the pathogenesis of $\mathrm{HBV}$.

\begin{abstract}
Abbreviations
ALT: Alkanine aminotransferase; ApoC3: Apolipoprotein C3; AST: Aspartate aminotransferase; BMI: Body mass index; CD82: Cluster of differentiation82; ECL: Electrochemiluminescence; ELISA: Enzyme-linked immunosorbent assay; HBV: Hepatitis B virus; HDL-C: High-density lipoprotein cholesterol; Interleukin: IL; LDL-C: Low-density lipoprotein cholesterol; LPL: Lipoprotein lipase; n: number of the subjects; NC: Nitrocellulose; PBS: Phosphate-buffered saline; RT-qPCR: Real-time quantitative polymerase chain reaction; SDSPAGE: Sodium dodecyl sulfate-polyacrylamide gel electrophoresis; TC: Total cholesterol; TG: Triglyceride; TG: Triglyceride; TRL: Triglyceride lipoprotein; VLDL: Very-low-density lipoprotein
\end{abstract}

\section{Acknowledgements}

We would like to thank all the volunteers for participating in the study.

\section{Funding}

This study was supported by Pudong New Area Science and Technology Development Fund(No.PKJ2016-Y56), the key specialty construction Project of Shanghai Municipal Health Bureau (No. ZK2015B16), the National Science Foundation of China (No.81672079, 30,973,073, 81,172,042), the Open Research Program of the State Key Laboratory of Virology of China (No.2016KF003) and the Disciplines Group Construction Project of Pudong Health Bureau of Shanghai (No. PWZxq2017-15).

\section{Availability of data and materials}

All data supporting the conclusions of this study are included within the article.

\section{Authors' contributions}

CLZhu participated in the cell culture, transfection, RT-qPCR and western blot. HCZhu provided the samples. HS and LMX measured serum lipid, LXL and FLiu performed the statistical analysis, XHLiu participated in the design, edited and revised the MS. All authors read and approved the final manuscript.

\section{Ethics approval and consent to participate}

This study was approved by the Ethics Committee of Wuhan University People's Hospital, and all subjects signed the informed consent.

\section{Consent for publication}

Not applicable.

\section{Competing interests}

The authors declare that they have no competing interests.

\section{Publisher's Note}

Springer Nature remains neutral with regard to jurisdictional claims in published maps and institutional affiliations.

\section{Author details}

${ }^{1}$ Department of Clinical Laboratory, Renmin Hospital of Wuhan University, Wuhan, Hubei 430060, People's Republic of China. ${ }^{2}$ Department of Clinical Laboratory, Shanghai Gongli Hospital, the Second Military Medical University, Pudong New Area, Shanghai 200135, China. ${ }^{3}$ Department of Neurology, Shanghai Gongli Hospital, the Second Military Medical University, Pudong New Area, Shanghai 200135, China. ${ }^{4}$ The State Key Laboratory of Virology, College of Life Sciences, Wuhan University, Wuhan, Hubei 430072, People's Republic of China.

Received: 27 September 2017 Accepted: 5 November 2017

Published online: 13 November 2017

\section{References}

1. Makvandi M. Update on occult hepatitis B virus infection. World J Gastroenterol. 2016;22:8720-34

2. Tarocchi M, Polvani S, Marroncini G, Galli A. Molecular mechanism of hepatitis B virus-induced hepatocarcinogenesis. World J Gastroenterol. 2014; 20:11630-40.

3. Gonzales JC, Gordts PL, Foley EM, Esko JD, Apolipoproteins E. AV mediate lipoprotein clearance by hepatic proteoglycans. J Clin Invest. 2013;123: 2742-51.

4. Li Y, Li C, Gao J. Apolipoprotein C3 gene variants and the risk of coronary heart disease: a meta-analysis. Meta Gene. 2016;9:104-9.

5. Pavlic M, Valero R, Duez H, Xiao C, Szeto L, Patterson BW, Lewis GF. Triglyceride-rich lipoprotein-associated apolipoprotein C-III production is stimulated by plasma free fatty acids in humans. Arterioscler Thromb Vasc Biol. 2008;28:1660-5.

6. Taskinen MR, Boren J. Why is apolipoprotein CIII emerging as a novel therapeutic target to reduce the burden of cardiovascular disease? Curr Atheroscler Rep. 2016;18:59.

7. Timpson NJ, Walter K, Min JL, Tachmazidou I, Malerba G, Shin SY, Chen L, Futema $M$, Southam $L$, lotchkova $V$, et al. A rare variant in APOC3 is associated with plasma triglyceride and VLDL levels in Europeans. Nat Commun. 2014;5:4871.

8. Shen T, WM W, WH D, Wang L, He G, Tan L, Wang Z, Chen R, Hu M, Ren YP. Positive association between serum apolipoprotein $M$ levels and hepatitis $B$ virus DNA load in HBeAg-negative chronic hepatitis B. Lipids Health Dis. 2016;15:210.

9. Wang FB, Zhu CL, Liu X, Gao GSHBV. Inhibits apoB production via the suppression of MTP expression. Lipids Health Dis. 2011;10:207.

10. Wang Y, Hao J, Liu X, Wang H, Zeng X, Yang J, Li L, Kuang X, Zhang T. The mechanism of apoliprotein A1 down-regulated by hepatitis $B$ virus. Lipids Health Dis. 2016;15:64

11. Zhu C, Gao G, Song H, Xu F, Wu K, Liu X, Hepatitis B. Virus inhibits apolipoprotein A5 expression through its core gene. Lipids Health Dis. 2016; 15:178.

12. Zhang R, Cao Y, Bai L, Zhu C, Li R, He H, Liu Y, Wu K, Liu F, Wu J. The collagen triple helix repeat containing 1 facilitates hepatitis $B$ virusassociated hepatocellular carcinoma progression by regulating multiple cellular factors and signal cascades. Mol Carcinog. 2015;54:1554-66.

13. Konishi $\mathrm{M}, \mathrm{CH}$ W, Inhibition WGY. Of HBV replication by siRNA in a stable HBV-producing cell line. Hepatology. 2003;38:842-50.

14. Sells MA, Chen ML, Acs G. Production of hepatitis B virus particles in Hep G2 cells transfected with cloned hepatitis B virus DNA. Proc Natl Acad Sci U S A. 1987;84:1005-9.

15. Norton PA, Gong Q, Mehta AS, Lu X, Block TM, Hepatitis B. Virus-mediated changes of apolipoprotein mRNA abundance in cultured hepatoma cells. J Virol. 2003;77:5503-6.

16. Jiang W, Zheng L, Yang Q, Huang Z, Wang X. Investigation into the effect of hepatitis B virus on apoliprotein A1 expression and its mechanism. Lipids Health Dis. 2014;13:130. 
17. Ponziani FR, Pecere S, Gasbarrini A, Ojetti V. Physiology and pathophysiology of liver lipid metabolism. Expert Rev Gastroenterol Hepatol. 2015;9:1055-67.

18. Song le H, Binh VQ, Duy DN, Kun JF, Bock TC, Kremsner PG, Luty AJ. Serum cytokine profiles associated with clinical presentation in Vietnamese infected with hepatitis B virus. J Clin Virol. 2003;28:93-103.

19. Xiang XG, Xie Q. IL-35: a potential therapeutic target for controlling hepatitis B virus infection. J Dig Dis. 2015;16:1-6.

20. Zhu C, Zhang R, Liu L, Rasool ST, Mu Y, Sun W, Hao Q, Liu F, Zhu Y, Hepatitis WJ. B virus enhances interleukin-27 expression both in vivo and in vitro. Clin Immunol. 2009;131:92-7.

21. Hsu CS, Liu CH, Wang CC, Tseng TC, Liu CJ, Chen CL, Chen PJ, Chen DS, Kao $\mathrm{JH}$. Impact of hepatitis $\mathrm{B}$ virus infection on metabolic profiles and modifying factors. J Viral Hepat. 2012;19:e48-57.

22. Vere CC, Streba CT, Streba L, Rogoveanu I. Lipid serum profile in patients with viral liver cirrhosis. Med Princ Pract. 2012;21:566-8.

23. Arzumanyan A, Friedman T, Kotei E, Ng IO, Lian Z, Feitelson MA. Epigenetic repression of $\mathrm{E}$-cadherin expression by hepatitis $\mathrm{B}$ virus $\mathrm{x}$ antigen in liver cancer. Oncogene. 2012;31:563-72.

24. Park IY, Sohn BH, Yu E, Suh DJ, Chung YH, Lee JH, Surzycki SJ, Lee YI. Aberrant epigenetic modifications in hepatocarcinogenesis induced by hepatitis B virus X protein. Gastroenterology. 2007:132:1476-94.

25. Yan J, Lu Q, Dong J, Li X, Ma K, Cai L, Hepatitis B. Virus X protein suppresses caveolin-1 expression in hepatocellular carcinoma by regulating DNA methylation. BMC Cancer. 2012;12:353.

26. Yu G, Bing Y, Li W, Xia L, Liu Z, Hepatitis B. Virus inhibits the expression of CD82 through hypermethylation of its promoter in hepatoma cells. Mol Med Rep. 2014;10:2580-6.

27. Larsson M, Allan CM, Jung RS, Heizer PJ, Beigneux AP, Young SG, Fong LG. Apolipoprotein C-III inhibits triglyceride hydrolysis by GPIHBP1-bound LPL. J Lipid Res. 2017;58:1893-902.

28. Larsson M, Vorrsjo E, Talmud P, Lookene A, Olivecrona G, Apolipoproteins CI. C-III inhibit lipoprotein lipase activity by displacement of the enzyme from lipid droplets. J Biol Chem. 2013;288:33997-008.

29. Ginzinger DG, Clee SM, Dallongeville J, Lewis ME, Henderson HE, Bauje E, Rogers QR, Jensen DR, Eckel RH, Dyer R, et al. Lipid and lipoprotein analysis of cats with lipoprotein lipase deficiency. Eur J Clin Investig. 1999;29:17-26.

30. Lopez-Miranda J, Cruz G, Gomez P, Marin C, Paz E, Perez-Martinez P, Fuentes FJ, Ordovas JM, Perez-Jimenez F. The influence of lipoprotein lipase gene variation on postprandial lipoprotein metabolism. J Clin Endocrinol Metab. 2004:89:4721-8.

31. Braschi S, Couture N, Gambarotta A, Gauthier BR, Coffill CR. Sparks DL, Maeda N, Schultz JR. hepatic lipase affects both HDL and ApoB-containing lipoprotein levels in the mouse. Biochim Biophys Acta. 1998;1392:276-90.

32. Chatterjee C. Sparks DL. Hepatic lipase, high density lipoproteins, and hypertriglyceridemia. Am J Pathol. 2011;178:1429-33.

33. Nicoll A, Lewis B. Evaluation of the roles of lipoprotein lipase and hepatic lipase in lipoprotein metabolism: in vivo and in vitro studies in man. Eur J Clin Investig. 1980;10:487-95

34. Jiang Y, Ma J, Li H, Liu Y, You C. Effect of apolipoprotein C3 genetic polymorphisms on serum lipid levels and the risk of intracerebral hemorrhage. Lipids Health Dis. 2015;14:48.

35. Su S, Tang M, Zhang M, Cheng C, Tang X. The relationship between apolipoprotein CIII gene polymorphism and serum lipid levels in Han Chinese males. Meta Gene. 2013:1:58-64.

\section{Submit your next manuscript to BioMed Central and we will help you at every step:}

- We accept pre-submission inquiries

- Our selector tool helps you to find the most relevant journal

- We provide round the clock customer support

- Convenient online submission

- Thorough peer review

- Inclusion in PubMed and all major indexing services

- Maximum visibility for your research

Submit your manuscript at www.biomedcentral.com/submit

) Biomed Central 